\section{- Concluding Thoughts}

As recognized in the Water Directive Framework, implementing a basin management approach in the EU will involve extensive co-ordination and integration across multiple national and sub-national jurisdictions. Experience in the US suggests that watershed based initiatives can be effective institutional innovations for addressing the range of complexities associated with water and related resource management. Their flexibility and nonprescribed forms may be key to these accomplishments, and as in the US, the EU is likely to see major management innovations achieved by the interactions of agency and non-governmental actors across the variety of river basin landscapes.

\section{References}

(1) For example, Leach, W.D.: Evaluating Watershed Partnerships in California: Theoretical and Methodological Per- spectives. Dissertation, University of California, Davis 2000; Genskow, K.D.: Critical Factors for Watershed Partnerships: An Analysis of Actions and Accomplishments. Doctoral Dissertation, University of Wisconsin, Madison 2001.

(2) Born, S.M./ Genskow, K.D.: The Watershed Approach: An Empirical Assessment of Innovation in Environmental Management. In: National Academy of Public Administration: Environment.Gov: Transforming Environmental Protection for the 21st Century. Research Papers 7-10, Volume II, 2000. Internet: http://www.napawash.org/pc_economy_environment/recent_publications.html

(3) Born, S.M./ Genskow, K.D.: Exploring the Watershed Approach: Critical Dimensions of State-Local Partnerships. River Network 1999 (free download at www.rivernetwork.org). (4) Kenney, D.S./ McAllister, S.T./ Caile, W.H./ Peckham, J.S.: The New Watershed Source Book: A Directory and Review of Watershed Initiatives in the Western United States. Natural Resources Law Center, University of Colorado School of Law 2000; Margerum, R.D.: Integrated Environmental Management: The Foundations of Successful Practice. In: Environmental Management, Vol. 24 (1999),
Nr. 2, S. 151-166; Born, S. M./ Genskow, K. D.: Toward Understanding New Watershed Initiatives: A Report From the Madison Watershed Workshop. University of Wisconsin 2001. Available on the internet at www.tu.org/newsstand/library_pdfs/watershed.pdf

\section{Die Autoren}

Kenneth D. Genskow is lecturer at the University of Wisconsin - Cooperative Extension, Stephen M. Born is professor at the Department of Urban and Regional Planning and the Institute for Environmental Studies at the University of Wisconsin.

Contact: Kenneth Genskow, University of Wisconsin, Environmental Resources Center, Cooperative Extension, 102 Smith Hall, HIRAM, 1545 Observatory Drive, Madison, WI 53706, USA.

E-mail: kgenskow@facstaff.wisc.edu; smborn@facstaff.wisc.edu

\section{Do Water Parliaments and Fees Pay?}

\section{In Frankreich haben flussgebietsbezogene Managementansätze eine lange Tra- dition. Die Umsetzung der Wasserrahmenrichtlinie war daher unproblematisch. Das neve Wassergesetz stellt im Kern eine Weiterentwicklung bewährter Insti- tutionen und Instrumente dar. Von Bedeutung sind hier insbesondere die staat- lichen Flusseinzugsgebietsagenturen sowie die so genannten Wasserparla- mente, die die Stakeholder einbinden. Auf der Ebene der Instrumente wird das bereits eingeführte Instrument der Nutzungsgebühren noch erheblich ausgewei- tet. Während Partizipation und Selbstverwaltung sicher auf dem Habenkonto des französischen Beispiels verbucht werden können, bleibt fraglich, inwieweit dadurch tatsächlich Umweltverbesserungen erreicht werden.}

\footnotetext{
A

Von Jan C. Bongaerts fter the adoption in October 2000 and the publication in December 2000 of the European Union Water Framework Directive (EU WFD), member states have to start with the transposition and the actual implementation of international water policy and water resources management. For France, the EU WFD is familiar, because the principle of water resources management at the level of river basins, as contained in the Directive, has already been established by the Water Act of 1964 . Hence, it is not surprising to see that, just a little more than one year after the publication of the EU WFD, the
}

French Parliament adopted a proposal for a Water Act which is to replace the Water Act of 1964 (and the important amendments of 1992) in the night of 10 January 2002.

We will examine the proposal in the light of the institutional arrangements and instruments of French water policy and water resources management. The proposal contains six chapters, three of which are of particular interest:

1. Decentralisation and planning of the management of water resources;

2. services publics for the provision of water and waste water treatment
3. reform of the river basin agencies.

\section{Decentralisation and Planning}

The French system comprises the following six river basins: Artois-Picardie, Rhin-Meuse, Seine-Normandie, Loire-Bretagne, Adour-Garonne, RhoneMéditerrannée-Corse. For each of these river basins, appropriate management organisations have been installed. The principal objectives and strategies of each river basin are contained in the socalled Schéma Directeur de l'Aménagement et de Gestion des Eaux - SDAGE (Principal Guidelines on Water Resources Management). The SDAGE contain descriptions of the overall objectives and the main strategies as well as more detailed documents on actual implementation, including maps. They were adopted for the first time in 1997 after the amendments of the Water Act in 1992. In the future, these SDAGE will keep their original function and also serve as the plans for water resources management which are required by Article 13 of the EU WFD.

At regional and local level, the SDAGE can be complemented by so-called SAGE (Schéma d'Aménagement et de Gestion des Eaux). The new proposal will improve the functioning of such SAGE by a better definition of the rights and obligations of local joint public bodies, such as a group of townships or of local governments, in particular as executive bodies, e.g. as contractors or/ and operators of public works. 
In this context, chapter 1 of the proposal contains a set or arrangements for the proper operating and functioning of sewerage systems obligations and responsibilities of emitters into such systems, in particular for non-domestic waste water -, the abstraction of water from water bodies, the change of course or volume of a water body and rights of trespassing by public authorities for the benefit of water resources management. These administrative procedures are far from spectacular but they tend to determine the relationship between individuals and the representatives of the State as the provider of water resources management services under the principle of service public.

\section{- Services Publics for Water Services}

Chapter 2 is devoted to the institutional and economic arrangements governing the provision of drinking water and waste water treatment. In this context, institutional arrangements refer to the management structure of a river basin which comprises

- political decision makers: the regional councils (les Conseils régionaux), the locally elected representatives, the local representatives of the national government and the mayors, who are ultimately responsible for the distribution of water and the supply of waste water treatment services; - public administrations with, at the centre, the Agence de l'eau as the main executive body, receiving assistance from other public administrations such as the regional representations of the national ministries;

- ad-hoc decision-making bodies (comités de bassin), often referred to as ,water parliaments“ composed of representatives of (public and private) affected parties whose main task is to set the broad policy guidelines, including those contained in the SDAGE.

The economic arrangements relate to the allocation of the costs for the provision of the services, e.g. drinking water, waste water treatment, extraction of surface water and groundwater, transportation, hydro-electricity, fishing and leisure. The proposal does so under the overall guidance of the principle of service public.

In this context, the proposal aims at the improvement of transparency. Whilst it clearly determines a responsibility of the communes for the provision of drinking water and waste water treatment services, it sets rules for communication and advice by the affected parties on actual policy-ma- king, i.e., regulatory arrangements such as bylaws or model contracts, reports on the quality of the services rendered and on their performance, proposals for tariff schemes and multi-annual investment plans. Mayors are obliged to consult with the affected parties, grouped into appropriately appointed bodies known as Commissions consultatives des services publics locaux according to procedures specified in the proposal. In terms of the provision of drinking water, it confirms the responsibility of the communes, including the basic right of every person ,in precarious conditions" of access to drinking water, irrespective of billing. For domestic users with an income below a certain threshold level, a tariff for basic needs will have to be installed.

Finally, the proposal installs a so called High Council for the services publics of drinking water and waste water treatment. Its task is to contribute to the regulation of these services ,through the analysis of the costs, the quality of the services and the characteristics and the performance of the works and the deliveries."

Given the structure of this body, it appears that this council is not a regulation agency, since it only has an advisory status, albeit on a very high level. One might consider it as performing the function of an „Ombudsman“.

\section{Reform of the River Basin Agencies}

In essence, the tasks and the activities of the river basin agencies are not modified. The important innovation is to be seen in the fact that, in the future, their legitimation is now granted by the national parliament. With the adoption of the law, the parliament will determine the priorities and the guidelines through legislation and leave it to the agencies to regulate the details - in cooperation with their Comités de bassin.

\section{Water Parliaments}

Inofficially known as the water parliament, the Comité de bassin represents the affected parties (stakeholders) of water resources management. They are grouped into several collèges according to the different stakeholders.

The water parliament meets at regular and scheduled time intervals - two to three times per year - and the minutes of the meetings are made public. It has three basic functions:

- Preparation of the principal guidelines (SDAGE) for approval by central government and - after formal adoption - monitoring of its implementation

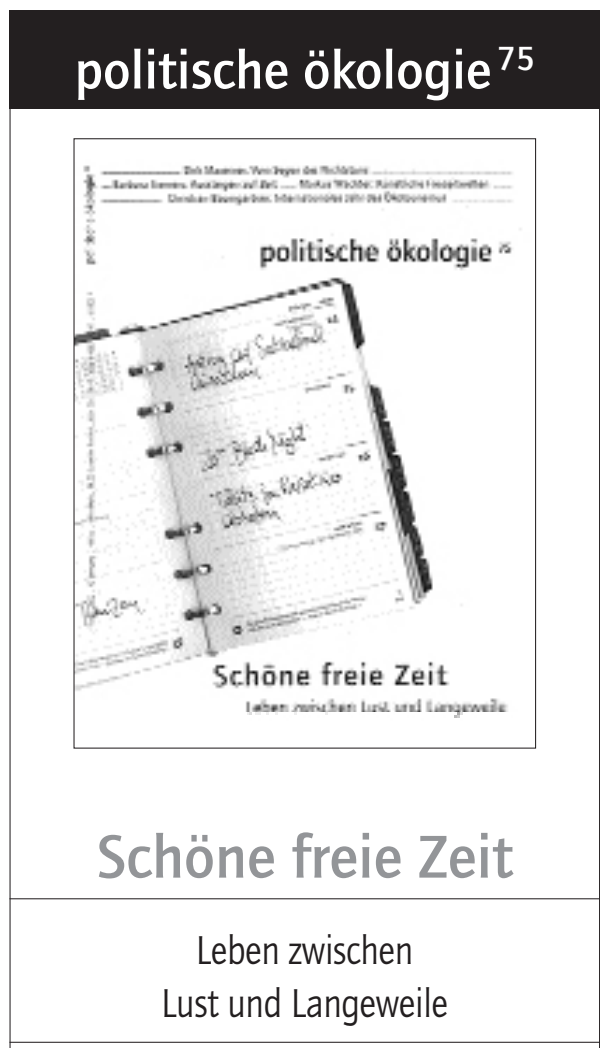

Wer sein Leben lang nur schuftet, verpasst sie vielleicht: Die schöne freie Zeit. Das aktuelle Themenheft spürt nach den Optionen, die Freizeit bietet. Nicht die Arbeit steht im Vordergrund, vielmehr kommt der Müßiggang zu Wort. Häufig belächelt als faule Daseinsform wird die gesellschaftliche Bedeutung der Muße unterschätzt, steht sie doch für eine maßvolle Lebensund Wirtschaftsweise. Andererseits halten Spaß- und Erlebniskultur Wirtschaft und Gesellschaft am Laufen: ob durch Trendsportarten, sozial- und umweltverträglichen Tourismus oder ehrenamtliches Engagement. Die politische ökologie 75 zeigt, wieviel Unheil allein durch sinnvolles Nichtstun verhindert werden kann.

Mit Beiträgen von Dirk Maxeiner, Jürgen P. Rinderspacher, Sybille Kallas, Barbara Siemens, Michael Pries, Markus Wachter, Ulrike Schumacher u.v.a.

\section{www.oekom.de}

Für 10,00 Euro erhältlich bei pan adress

Semmelweisstraße 8, D-82152 Planegg

Fon $++49 /(0) 89 / 857$ 09-155

Fax ++49/(0)89/857 09-131

E-Mail kontakt@oekom.de 
and of progress made. This may include advice on the local management plans ( $S A G E)$;

- giving guidance to the work of the river basin agency by adopting the grants programme. This includes decision-making on the water resources user fees (redevances);

- giving advice on all issues dealing with water policy and water resources management, in particular with respect to the grants programme and works of infrastructure.

Moreover, the water parliament has an important role to play in the nomination of the board of the agency. Hence, this board will be composed of a president appointed by decree by the President of the Republic, representatives of central government as well as representatives of the regional and local governments, of users and NGOs and one representative of the staff of the agency.

\section{Water Resources User Fees}

One of the key instruments of French water policy and water resources management is the levying of charges for the use of water resources (abstraction) and of water bodies as recipients of effluents (discharges). Known as redevances they are genuinely to be considered as user fees with respect to (the impairment of) water bodies. Hence, the principle holds that the use of a water body is not free but, instead, requires the payment of a fee.

The proposal contains a reform and extension of these user fees to set rules for the determination of actual pollution as caused by various actors. Within the category of pollution, a distinction is made between point sources and diffuse sources. With respect to pollution from point sources, a distinction is made among various subcategories as for example households pollution, urban pollution, industrial and comparable pollution and pollution from waste water treatment.

\section{Organisationales Lernen und die Umweltleistung} von Unternebmen

ist das Thema des Informationsdienstes

\section{Ökologisches Wirtschaften 5/02}

Wenn Sie potenzielle Beiträge haben, wenden Sie sich bitte an die Redaktion.
For the calculation of the fees, so-called threshold levels are introduced. On the basis of these threshold levels, the quantities of pollution for which redevances are set can be determined. In this respect, the new law simplifies matters because, in the future, these quantities refer to pollution actually released into the environment.

Even so, this means that information on the pollution quantities in the incoming waste water is necessary in order to determine the net quantities of pollution. For individual households this information is provided by estimates leading to an average or standard quality of a $\mathrm{m} 3$ of waste water. For large emitters, such as firms, this estimation procedure is also allowed but, upon the request by such an emitter, the river basin agency may determine the actual quantities of pollution on the basis of a self-monitoring activity. The guidelines for this procedure are determined with the purpose of enabling the agency to determine total pollution in the river basin and, in consequence, the appropriate user fees. Firms have the obligation to cooperate with the agency for this purpose. For the determination of households pollution, a standardised approach is used.

Some examples of new redevances as contained in the proposal:

- Waste water treatment: Shift of legal responsibility for payment by individuals and firms to payment of fees by local governments actually generating effluents and the calculation of fees based upon the number of inhabitants within the sewerage catchment areas.

- Diffuse sources: Introduction of a fee on excess nitrogen, the calculation of excess nitrogen is based upon an input-output accountancy as well as rebates for nitrogen absorbing technologies, e.g., pasture land (grassland) and of cultivated fields out of production season.

- Modification of course or volume of a water body: New fees on activities of deviation implying reductions of volume of water bodies, on important obstacles with negative impacts on the mobility of aquatic organisms as well as the storage of water resources. They are based upon the impact of the activity on the volume of the water body as well as the length of a river impaired by the activity.

\section{Conclusions}

The concept of river basin management of water resources has a long tradition in France. In this sense, future EU water policy and water resources is inspired by this tradition. The reform of the French Water Act of 1964 has been adopted by the national parliament on 10 January 2002 in order to transpose the EU WFD into French law and water policy and water resources management. From the French point of view, institutional arrangements at the level of river basins and water resources user fees are important instruments for policy-making and management in the line of transparency, democracy and solidarity under the principle of service public.

One important issue relates to the question whether the river basin approach leads to a better environmental performance in comparison to other administrative approaches. This question is very difficult to answer in practice, since one would have to study actual data about the quality of water bodies and relate these to administrative structures. The outcome of such a investigation is uncertain. At the conceptual level, the river basin approach allows for an integration of all usages of a water body ,from source to mouth“. This might be seen as an advantage not shared by fragmented administrative structures.

One weak point of the French system can be seen in the powers of the water parliaments to set their own redevances. On the one hand, this procedure reflects the participative characteristics of the river basin approach, on the other hand, it acts as a disincentive for setting these fees at very high levels, which might be ecologically relevant. The new law tends to correct for this dilemma by giving a clear legislative guidance to this procedure which is to be taken into account by the water parliaments.

Another element of French water policy and water resources management which is only partially related to the river basin approach are the user fees themselves. One has the impression that there is a strong political will to put a price on virtually every kind of usage on the basis of the polluterpays-principle. Whilst these fees produce earmarked budgets for the river basin agencies from which they can award grants, one might ask the question whether this really leads to better ecological performance.

\section{Der Autor}

Dr. Jan C. Bongaerts ist Professor für Umweltmanagement an der Technischen Universität - Bergakademie Freiberg und IÖW-Vorstand. Kontakt: TU Freiberg, Fachbereich 06, 09599 Freiberg. Tel. 03731/ 39-3018, E-mail: J-C.Bongaerts@ioez.tu-freiberg.de 
(c) 20I0 Authors; licensee IÖW and oekom verlag. This is an article distributed under the terms of the Creative Commons Attribution Non-Commercial No Derivates License (http://creativecommons.org/licenses/by-nc-nd/3.o/), which permits unrestricted use, distribution, and reproduction in any medium, provided the original work is properly cited. 